CANADIAN JOURNAL OF PHILOSOPHY

Volume 16, Number 2, June 1986, pp. 181-198

\title{
Dante's Hell, Aquinas's Moral Theory, and the Love of God
}

ELEONORE STUMP

Virginia Polytechnic Institute and State University Blacksburg, VA. 24061 U.S.A.

'Abandon all hope, ye who enter here' is, as we all recognize, the inscription over the gate of Dante's hell; but we perhaps forget what precedes that memorable line. ${ }^{1}$ Hell, the inscription says, was built by divine power, by the highest wisdom, and by primordial love. Those of us who remember Dante's vivid picture of Farinata in the perpetually burning tombs or Ulysses in the unending and yet unconsuming flames may be

1 This paper is an altered version of a lecture given to the Medieval Guild at the University of Alberta. I am grateful to the members of the Medieval Guild and to the other members of the audience for excellent discussion of the paper. 
able to credit Dante's idea that Hell was constructed by divine power; and if we understand 'wisdom' in this context as denoting an intellectual virtue only (and not as connoting a mixed moral and intellectual one), then we might agree that only divine wisdom is capable of making something like Dante's hell. But many of us would balk at the claim that love, God's great, pure, 'primordial' love, might play a part in producing a Dantean hell. Consider, for example, Dante's description of the wrathful. and their punishment:

This gloomy stream, when it has reached the foot of the... grey slopes, enters the marsh which is called Styx; and I, who had stopped to gaze intently, saw muddy people in that bog, all naked and with looks of rage. They were smiting each other not only with their hands but with their heads and chests and feet and tearing each other to pisces with their teeth. My good Master said, "Son, you see now the souls of those whom wrath overcame."2

One of those in this group is Filippo Argenti, a proud and quarrelsome Florentine noble.

While we were running through the stagnant channel there rose up before me a man covered with mud who said, "Who are you who come before your time?" And I said to him, "If I come, I do not stay. But you, who have become so foul, who are you?" He answered, "You see that I am one who weeps." And I said to him, "In weeping and in misery remain, accursed spirit, for I know you in spite of all your filth." Then he reached out to the boat with both hands; but my wary Master shoved him back, saying "Back down with the other dogs!" Then he flung his arms around my neck and kissed me, saying, "... blessed be the womb that bore thee!" ... And I said, "Master, I should like to see him drubbed down into the marsh before we leave this lake." ... Soon after I saw such a rending of him by the muddy crowd that I still give praise and thanks to God for it; all cried: "At Filippo Argenti!" and the passionate Florentine spirit turned on himself with his teeth. ${ }^{3}$

What we see in the case of Filippo Argenti, then, is a man who was given to wrath during his lifetime and who no doubt caused a significant amount of trouble in consequence, but who is punished for that finite

2 I have taken this translation, with some modification, from Dante's Inferno, tr. John D. Sinclair (Oxford: Oxford University Press 1974), Canto VII, 103-5.

3 I have taken this translation, with some modification, from Sinclair, Canto VIII, 113. 
fault and finite trouble with an unending torment of beatings and attacks in the swamp of the Styx. How is love, divine love, supposed to be shown to Filippo Argenti?

Now the problem concerning Dante's hell presupposes a certain notion of goodness. If we did not believe, for example, that inflicting pain is on the face of it evil, we would not wonder how to reconcile belief in a loving God with the claim that Filippo Argenti is perpetually tormented at God's command. But, of course, if this concern over evil is to be the basis for a serious objection to Christianity, it must be founded on the same concept of goodness as that employed by Christians. If we can prove, for example, that the existence of hell is incompatible with the existence of a good God, where by 'good' we mean 'pleasure-maximizing,' the result will hardly distress the Christians at whom it is aimed, because they never thought there was such a God. So before we ponder the problems raised by Dante's conception of hell, we need to consider Christian accounts of the nature of goodness.

There seem to be two main sorts of competing Christian theories concerning what is to count as good. ${ }^{4}$ Either God's will is taken to create morality, so that whatever God wills is good just because he wills it: consequently, (TS) right actions are right just because God approves of them and wrong actions are wrong just because God disapproves of them. Or morality is taken to be grounded independently of God, so that God frames his will in accordance with those independently existing standards of goodness: consequently, (TO) God approves of right actions just because they are right and disapproves of wrong actions just because they are wrong. The problem with (TS) is that it constitutes a theological subjectivism in which, apparently, anything at all could turn out to be moral. So although (TS) makes a consideration of God essential to an evaluation of human actions, it does so at the cost of depriving that evaluation of its moral character; because it cannot rule out anything as absolutely immoral, (TS) seems to be a theory of religious morality which has dropped morality as we commonly understand it out of the theory. There have been some interesting attempts to resuscitate one or

4 I have taken the discussion of the two sorts of theories of religious morality from 'Absolute Simplicity,' Eleonore Stump and Norman Kretzmann, Faith and Philosophy 2 (1985), 353-82. See also Norman Kretzmann, 'Abraham, Isaac, and Euthyphro: God and the Basis of Morality' in Hamartia: The Concept of Error in the Western Tradition, ed. Donald Stump et al. (Toronto: Edwin Mellen Press 1983), 27-50. 
another version of (TS) in recent years; ${ }^{5}$ but despite these promising efforts versions of (TS) are, I think, still more widely known for their faults than for their virtues, and so I will leave such theories to one side. (TO), on the other hand, obviously is a candidate for an objective theory of morality, since it does not make moral standards dependent on God's will; but it is commonly criticized on the grounds that it does not establish any essential connection between God and the standards for moral values. It seems to presuppose moral standards which exist apart from God and which God may promulgate but certainly does not produce. Furthermore, it appears as if on (TO) the standards to which God looks for deciding what is moral somehow exist independently of him in a way which seems to be dubious or mysterious and which seems to detract from God's sovereignty.

In the work of Thomas Aquinas, however, there is a philosophically interesting version of (TO) which is able to meet these criticisms. I want to show briefly what that version is and how it works, and then consider the results of bringing Aquinas's theory to bear on the problem raised by Dante's hell.

Aquinas's theory of morality relies first of all on the claim that God is simple. ${ }^{6}$ The doctrine of God's simplicity is notoriously complicated and controversial, but it sometimes seems more implausible than it really is because the doctrine has been misunderstood. ${ }^{7}$ Basically, the doctrine of simplicity is the notion of God's radical oneness, and it is comprised in three claims. First, it is impossible that God have any spatial or temporal parts that could be distinguished from one another as here rather than there or as now rather than then. Hence, God cannot be a physical entity. Secondly, the standard distinction between an entity's essential and

5 See, for example, Robert Merrihew Adams, 'A Modified Divine Command Theory of Ethical Wrongness' in Religion and Morality, ed. Gene Outka and John P. Reeder, Jr. (New York: Doubleday 1973), 318-47; 'Autonomy and Theological Ethics,' Religious Studies 15 (1979) 191-4; 'Divine Command Methaethics Modified Again,' Journal of Religious Ethics 7 (1979) 66-79; and Philip Quinn, Divine Commands and Moral Requirements (Oxford: Clarendon Press 1978).

6 See, for example, Summa theologiae (ST) Ia, q. 3; De potentia q. 7; and Summa contra Gentiles (SCG), Bk. I ch. 21-5.

7 For a fuller discussion and defense of the traditional doctrine of simplicity, see Stump and Kretzmann, 'Absolute Simplicity.' Some of the discussion of simplicity in what follows is taken from that paper. 
accidental intrinsic characteristics cannot apply to God; it is impossible that God have any intrinsic accidental characteristics. And thirdly, even when we have recognized that all God's intrinsic characteristics must be essential, we have to acknowledge as well that it is impossible for there to be any real, metaphysical distinction between one essential characteristic and another in God; whatever can be correctly attributed to God must in reality be identical with the unity that is his essence. Furthermore, for all things other than God, there is a difference between what they are and that they are, between their essence and their existence; to be characterized by a human nature is one thing, actually to exist as a human person is another. But on the doctrine of simplicity the essence which God is is not different from his existence. Unlike all other entities, God is his own being.

Clarification of these claims significantly reduces their counterintuitive character, I think. In the first place, these claims are limited to God's intrinsic characteristics. The distinction between intrinsic and extrinsic characteristics - or between real and 'Cambridge' properties - is a familiar one which is widely recognized although not always easy to draw. I do not know of a satisfactory set of criteria for making the distinction with precision, but perhaps an example will be sufficient here. Ronald Reagan's belief that he is of Irish descent is one of his intrinsic accidental characteristics; his being mentioned in this paper is an extrinsic accidental characteristic of his. Some entities, like numbers or like God in the doctrine of divine simplicity, have no intrinsic accidental characteristics; but no entity, not even a mathematical or a divine entity, can be exempted from having extrinsic accidental characteristics.

Secondly, by 'essential' and 'accidental' here Thomas does not mean what we today usually mean. We tend to understand an essential characteristic as one which a thing has in every possible world in which it exists. This is not what Thomas means by the term, at least not when he applies it to God. Instead what he means is something more like 'ineluc-

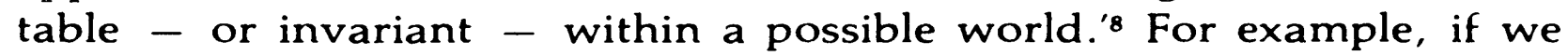
think about God as he creates the actual world, at the first moment of its existence, and if we think of the future of that world from that moment on as a branching tree with alternative futures as the branches, then a characteristic of God is essential in Aquinas's sense if God has it on every branch of the tree. According to the doctrine of simplicity, from God's first creating, his nature cannot vary from one branch to another

8 This view is argued for at length in Stump and Kretzmann, 'Absolute Simplicity.' 
of the world he chooses to create, although he might have chosen to create a different world with which he would have had different relations.

And finally the claim that there are no real distinctions among divine attributes such as omnipotence and omniscience should not be read as saying that the property of being omnipotent is identical with the property of being omniscient. On the contrary, Aquinas is careful to claim that terms referring to standard divine attributes are not synonymous. 9 Rather, on the doctrine of simplicity, God is identical with just one indivisible thing, but that one thing has different effects and appearances. God's talking to Cain is not the same as his talking to Abraham; but that undoubted distinction does not compromise God's simplicity, because these events are to be understood just as various temporal effects of the single eternal act which is God. Similarly, what we call God's omnipotence or God's omniscience is the single eternal action viewed under different descriptions or picked out with reference to different kinds of manifestations of it. Thus, what simplicity requires one to understand about all designations for the divine attributes is that they are identical in reference but different in sense; they refer in differing ways to the single thing in act which is God.

So on the doctrine of simplicity there are in reality no distinctions within the divine nature, and God is in some sense identical with whatever can be really attributed to him. But the respect in which God is devoid of real distinctions does not preclude our distinguishing God's actions in the world from one another and does not require our taking the terms for divine attributes as synonymous. On the doctrine of simplicity, then, there is something inaccurate in saying that God is omnipotent. It is more nearly correct to say that he is identical with omnipotence, but even that statement is misleading. Perhaps the best available formulation is that God is identical with the single indivisible act which he is, one of whose manifestations or partial descriptions is omnipotence.

In this much too brief exposition of a complicated idea, I have given just enough of Aquinas's idea to be able to show one of the uses to which he puts it. To begin with, on Aquinas's view, because God is simple, he is identical with his goodness; that is, in some sense it is true to say that the divine nature itself is preeminent goodness. Thus there is an essential relationship between God and the standard by which he judges. The

9 See, e.g., De potentia q. 7, a. 6; ST Ia, q. 13, a. 4; and SCG, Bk. I, ch. 35. 
goodness for the sake of which and in accordance with which he wills only certain things to be moral is identical with his nature. Hence, his sovereignty is not impugned by supposing that he judges in accordance with some objective standard, because the standard is his nature. And by the same token the existence of this standard is not something peculiar or mysterious, as the earlier objection to (TO) supposed, because the existence of the standard just is the existence of God. On the other hand, because it is God's whole nature and not his will alone which constitutes the standard for goodness, not just anything could theoretically be moral but only those things which are consonant with God's nature; and hence the dangers and drawbacks of theological subjectivism are avoided. So, on the doctrine of simplicity, God has an essential connection to morality; and yet that connection constitutes an cbjective rather than a subjective moral standard.

The doctrine of divine simplicity is one of the pillars on which Aquinas's moral theory is based. The other is Aquinas's identification of goodness and being, ${ }^{10}$ an identification which serves to turn what would otherwise be a vague and sketchy metaethics into a functioning moral system. ${ }^{11}$ On Aquinas's view, the terms 'goodness' and 'being' are the same in reference but different in sense. 'Being' refers to being, with the sense of something's being actual or being existent; 'goodness' refers to being also, but under the description and with the sense of something's being desirable. (Aquinas, in fact, frequently quotes with approval Aristotle's dictum that the good is what all desire.) ${ }^{12}$ The terms 'being' and 'goodness,' then, like the terms 'the morning star' and 'the evening star,' refer to the same thing in reality; both 'being' and 'goodness' pick out the actualization of something. But they refer to it under different descriptions and with different senses; and so they are not synonymous, just as the terms 'the morning star' and 'the evening star' are not synonymous although they both refer to Venus.

10 See, e.g., ST Ia, q. 5, and De veritate q. 21 a 1-2.

11 For a much fuller discussion and defense of Aquinas's theory of the nature of goodness, see 'Being and Goodness,' Norman Kretzmann and Eleonore Stump, Divine and Human Action: Essays in the Metaphysics of Theism, ed. Thomas Morris (Ithaca, N.Y.: Cornell University Press, forthcoming). For a study of this theory in the medieval period prior to Aquinas, see Scott MacDonald, 'The Metaphysics of Goodness in Medieval Philosophy Before Aquinas,' Ph. D. dissertation, Cornell University, 1985.

12 See, e.g., ST Ia, q. 5, a. 1. 
This identification of being and goodness sounds initially more than a little implausible. It seems to follow from this claim, for example, that the more there is of Ronald Reagan, the better he is, so that he should be prevented from dieting as a service to the nation. And it also seems to entail that whatever is is good, and is good solely in virtue of being; but it is our common intuition that many of the things which are are bad. To understand why these and the many other apparent objections which could be raised against Aquinas's theory are not in fact effective against it, we need to understand better what Aquinas means by 'being.'

Put very roughly, the relevant parts of Aquinas's metaphysics are these. On Aquinas's view, everything has a nature; that nature is essential to the thing in question and is necessarily shared by all members of its kind. ${ }^{13}$ A description of such a nature is not a complete specification of the characteristics of the thing which has it, but it is a complete specification of the species or genus to which the thing belongs. The standard example given by the scholastics is for human nature. On medieval views, a human being - say, Nathan - is a rational animal. The description rational animal is not enough to pick out Nathan, but it does specify the kind to which Nathan belongs. Anything which is human is a rational animal, and anything which is a rational animal is human. Now on Aquinas's view anything that comes into existence comes into existence as a thing of some species, and for something to be is for it to be a thing of a certain kind. For a human being such as Nathan to be is for a particular instance of the species rational animal to be actual. 'Being' in this sense typically means existence; and the ordinary sense of the term 'being' is the existence of an instance of some species.

To understand the ordinary sense of the term 'goodness' we need to look more carefully at the description of a thing's essential nature. For Aquinas, human nature is specified by two words, 'rational' and 'animal.'14 'Animal' picks out the broader group or genus to which human beings belong. 'Rational,' on the other hand, indicates a capacity peculiar to and definitive of the species. And on Aquinas's view, the nature of anything will always be correctly described in the same sort of way; it will be picked out by a genus and a capacity characterizing a particular species. ${ }^{15}$

13 See, e.g., In XII libros Metaphysicorum Aristotelis expositio, Bk. V. L. 5; nn. 822-6 and Bk. VIII, L. 2, n. 1697.

14 See, e.g., In XII libros Metaphysicorum Aristotelis expositio, Bk. V. L. 5, n. 822; Bk. V, L. 12, nn. 916-17 and 931; and Bk. VII, L. 3, n. 1326.

15 Cf., e.g., In XII libros Metaphysicorum Aristotelis expositio, Bk. V, L 5, n. 822 
As the specific capacity of anything is actualized by being exercised, the nature of that thing is progressively completed or perfected, according to Aquinas. ${ }^{16}$ Such a completing or fulfilling of a thing's nature can be thought of in two ways. On the one hand, to the degree to which a thing's nature is perfected or fulfilled, it is a good instance of the kind of thing it is. And so the goodness of a thing is tied fundamentally to its fulfillment of its nature. ${ }^{17} \mathrm{~A}$ thing $x$ of a kind $K$ is a good $K$ primarily to the extent to which it has actualized the capacity specific to that kind. Nathan is good as a human being to the extent to which he has actualized the capacity specific to human nature. ${ }^{18}$ On the other hand, as any capacity is actualized, something which was not in fact in being but was only potential becomes actual. Hence, by the actualization of a capacity, being is increased. And it is to such an increase of being recognized or conceived of as desirable that the term 'goodness' refers. In this way, then, the terms 'goodness' and 'being' both refer to being, on Aquinas's account; but the ordinary sense of 'being' is the existence of an instance of some species, and the ordinary sense of 'goodness' is the fulfillment of a thing's nature, which is brought about by the actualization of its specific capacity. ${ }^{19}$

and L. 7, nn. 861-4; and Bk. VII, L. 3, n. 1327. For the view that rationality (and other characteristics which are the differentiae of species) are capacities, cf., e.g., In XII libros Metaphysicorum Aristotelis expositio, Bk. V, L. 5, n. 825 and more generally Bk. IX, L. 3 and L. 4.

16 See, e.g., In XII libros Metaphysicorum Aristotelis expositio, Bk. IX, L. 8, nn. $1856,1860,1865$.

17 Cf. SCG Bk. I, c. 37-39 and Bk. III, c. 6-7, 11-12, and 38-39; and De veritate, q. 21, a. 3.

18 By 'has actualized' here I mean something like 'has acq: ired the disposition to operate in accordance with reason.' According to Aquinas, the function of anything is derived from its characteristic form, which is its first perfection; its function or operation is its second perfection. In the case of man the function derived from the form is living according to reason, and virtue is a disposition to act in accordance with reason. Cf. $x$ libros Ethicorum Aristotelis expositio Bk. I, L. 10. See also ST Ia IIae, q. 55, a. 1, where Aquinas describes a virtue as a habit which is the perfection of the rational power proper to human beings. And in ST Ia Ilae q. 49, a. 2, he defines a habit as the determination of a subject in regard to the nature of a thing. Moreover, nothing in the locution has actualized its specific capacity' should be taken to mean that a moral human being is so solely in virtue of his essence. On Aquinas's view, the disposition to act in accordance with reason is accidental to a person (because it is a habit and thus a quality) and added to his essence. Cf. De veritate q. 21, a. 5 and ST la Ilae, q. 49, a. 2.

19 For more of Aquinas's discussion connecting a thing's goodness and its species, cf. ST Ia, q. 5, a. 5 and De veritate, q. 21, a. 6. 
On this theory, what makes a human being good as a human being (as distinct from good as a politician or good as a poet) is the exercise and actualization of rationality, which is the capacity specific to human beings. ${ }^{20}$ And that the actualization of the capacity for reason makes one good as a human being is explained, on Aquinas's metaethical theory, by the fact that such an actualization constitutes an increase of being, and that the term 'goodness' refers to being. So, to return to the objections I raised initially, Aquinas's theory does not entail that an increase in Ronald Reagan's weight is an increase in his goodness, because his added weight does not constitute any actualization of his capacity for reason. On the contrary, if Reagan's weight gain would make him overweight for his height and build, it would be against reason since being overweight jeopardizes health by increasing the likelihood of premature death from heart attacks (among other things). A person who dies prematurely diminishes his being by losing years of his life; but to diminish being is bad, and to do something bad without an overriding good end which justifies it is irrational. Aquinas's theory also easily meets the other objection, that some things exist but are not good. Because Aquinas takes 'being' and 'goodness' to refer to the same thing, he is committed to the claim that everything which is is good, on a certain interpretation of this claim; but the interpretation warranted by his theory is compatible with the claim that some existent things are bad. For Aquinas anything which exists has goodness in some degree or in some respect, but that degree of goodness is not sufficient to merit calling the thing as a whole good because the ordinary sense of the term 'good' is the actualization of that thing's specific capacity. And so a thing may exist and still be correctly considered bad on Aquinas's theory, because although it has a certain amount of being just in virtue of existing, it falls far short of the degree of being it would have if it had completely actualized the capacity comprised in its essential nature. ${ }^{21}$

Insofar as a good human being is a moral one, for Aquinas a rational action is always a moral action. And the system of values on which one determines which act is rational will also involve the identification of being and goodness. To take a very simple-minded example, it is wrong gratuitously to kill a dog, because it is irrational or against reason to do so. It is irrational to do so because killing the dog is the destruction of

Cf. ST Ia Ilae, q. 71, a. 2 .

21 Cf., e.g., ST Ia, q. 5, a. 3, esp. ad 2. 
some being; the destruction of being is by definition bad; and choosing something bad in the absence of some overriding good which justifies it is against reason. ${ }^{22}$

If we return to the instance of moral evil with which this paper began, the wrathfulness of those punished in the Styx in Dante's hell, we are now in a position to provide the analysis of wrath entailed by Aquinas's moral theory. What is striking about Filippo Argenti is the violence of his reaction to Virgil and Dante; there is an abvious disproportion between what they say or do to him and his reaction to them. And insofar as the strength of his negative reaction is greatly mismatched to the events which provoke it, his reaction is against reason. In general, on Aquinas's view, what makes wrath wrong and what distinguishes it from righteous indignation is that the wrathful reaction fails to be commensurate with the events to which it is a response. ${ }^{23}$

But, of course, the seeming incommensurability of God's response to human wrong-doing was the problem with which this paper began. Does Aquinas's theory require us to say that God is irrational in his treatment of sinners as Dante understands it? I don't think so. On the contrary, I think the claim that God is both rational and loving in the sort of punishment afforded sinners described in Dante's hell is consistent with the rest of Aquinas's moral theory. To see that this is the case, we need to look more closely at Aquinas's notion of God's love.

Put roughly, according to Aquinas, love is a passion that stimulates the lover to desire the good of what he loves and recognizes as good and that results in some sort of oneness between the lover and the object of his love. ${ }^{24}$ A full analysis of Aquinas's view of love is beyond the scope of this paper, but the gist of his view can perhaps be appreciated by focusing on his own abbreviated formula: to love a person is to will that person good. ${ }^{25}$ Although much more needs to be said about love between

22 This example is misleading because, of course, in any ordinary case killing a dog involves in fact a transformation of being; something inanimate is produced in place of something animate. To show that there is a destruction of being in such a case requires arguing that there is a hierarchy of being such that in the transition from animate to inanimate being is lost. Aquinas clearly does hold such a view; see, e.g., SCG Bk. III, c. 22.

23 Cf., e.g., ST Ia Ilae, q. 46, a. 4 and q. 48, a. 3. and esp. Ila Ilae, q. 158, a. 1 and a. 2 .

24 Cf. ST Ia, q. 20, a. 1 and Ia Ilae, q. 27, a. 2.

25 Cf. ST Ia, q. 20, a. 1, a. 2, and a. 3. 
human beings, even human love on Aquinas's view has as its main characteristic a desire for the good of the person loved. For God to love a human being, then, involves his doing what it is open to him to do to ensure the most good for that person; ${ }^{26}$ but the goodness of anything is the actualization of the capacity specific to that thing's nature, and so to desire the good of anything is to desire the fulfillment of its nature. We can perhaps circumvent some of these clumsy locutions by saying in summary fashion that, for Aquinas, to love something is to treat it according to its nature. Thus God's love for human persons consists essentially in treating them according to their nature; and so, given Aquinas's account of human nature, God's love for a person involves helping to maximize that person's capacity for reason.

Now this account may sound like a cold, even a hateful, notion of God's love; but that is entirely a mișimpression. Aquinas's view of love is in fact much more in harmony with our ordinary sense of what love should be than it at first appears to be. To begin with, we should remember that on Aquinas's view to actualize one's capacity for reason is to be a good human being and hence a moral human being. For Aquinas, a wrong action is an action done contrary to reason, and an action done in accordance with reason is a right action. That is why Aquinas describes a human virtue basically as a stable disposition to act in accordance with one's nature; ${ }^{27}$ it is a settled tendency to act rationally, that is, to act morally. There is no denigration of emotion in this elevation of reason, as there sometimes is in later periods among those who glorify reason. On Aquinas's view, for example, anger, unlike wrath, is an emotion in accordance with reason. ${ }^{28}$ Wrath is an emotion out of proportion to the events arousing it and so is neither rational nor moral. But anger is an emotion which is appropriate in its degree and intensity for the actions and individuals to which it is directed. That is why when Dante gets angry with Filippo Argenti, he is not himself in danger of remaining in the circle of the wrathful. On the contrary, Virgil, the personification of reason, praises him for his anger in the highest terms, because Dante's anger, unlike Filippo Argenti's wrath, is in accordance with reason.

26 Cf. ST Ia, q. 20, a. 1 ad 3, and a. 2.

27 ST Ia IIae, q. 71, a. 1 and a. 2. Cf. also ST Ia Ilae, q. 58, a. 1, ad 3; Ia Ilae, q. 55, a. 1 and a. 2 ad 1 and q. 56 a. 1 and a. 4.

28 ST IIa Ilae, q. 158, a. 1 and a. 2. 
So to treat human beings according to their nature consists of promoting in them moral actions, emotions not contrary to reason, and in general virtuous states of character. At this stage Aquinas's account should begin to look less cold and more in line with our common notions. We do not, after all, commonly take the best mother to be the one who maximizes pleasure for her children or who clings to them with the most emotion, for example; rather we generally assume that true maternal love involves a mother's trying hard to help her children develop into the best people they can be.

But, of course, disinterested promotion of a child's development into a good human being still falls far short of constituting maternal love; and in the same way, for the same sorts of reasons, we might still be quite dissatisfied with Aquinas's account of love. To find in Aquinas's theory what we sense is still needed, we should remember that, on Aquinas's view, the recognition of the beloved as gond and the desire for the beloved's good effect a union between the lover and his beloved. ${ }^{29}$ Aquinas dwells at length on the nature and causes of such a union. The lover is moved to seek the presence of his beloved, and the beloved is desired by the lover as another self. ${ }^{30}$ Because of his love, the lover seeks an intimate knowledge of the person he loves, and he strives to possess the beloved perfectly by knowing the heart and soul of the beloved. In the resulting union the lover and his beloved come to dwell in each other in that each abides continually in the apprehension and affections of the other ${ }^{31}$ For this reason, Aquinas says, love is called the uniting force. ${ }^{32}$ With this part of Aquinas's view of love brought to the fore, the last suspicions that his account is hatefully cold should be stilled.

Now insofar as things can be ranked in terms of goodness, to act rationally is to love more the things which are better; and so since God is preeminent goodness, on Aquinas's view he should be loved most of all. ${ }^{33}$ Of course, we may wonder how God can be loved if loving a thing includes promoting its goodness, because God's goodness is perfect and

29 ST. Ia, q. 20, a. 1 ad 3; Ia Ilae, q. 26, a. 2.

30 ST Ia Ilae, q. 28, a. 1 and 4. 26, a. 2; and Ia, q. 20, a. 1.

31 ST la Ilae, q. 28 , a. 2.

32 ST Ia, q. 20, a. 1.

33 ST IIa IIae, q. 26, a. 2 ad 1 and q. 27, a. 3; cf. also Ia, q. 20, a. 4 and la Ilae, q. 27, a. 1 . 
so cannot be promoted. But here it helps, I think, to remember the doctrine of simplicity. God is identical with goodness on that doctrine. So we could perhaps say that the love of God is constituted in part by the desire for and the promotion of goodness; to act out of love for God includes desiring and doing good just for the sake of goodness. If a person does will to do good for the sake of goodness, it is in some sense true to say that his will is in accord with God's will, and to that extent he is in unity with God. So, for more than one reason, on Aquinas's theory, to love God is to be united with him, to some extent during this life and perfectly in the afterlife.

To summarize this very brief account of a complicated part of Aquinas's philosophy, then, for God to love a person - Monica, for example, - is for God to treat Monica according to her nature. That means helping Monica to actualize her capacity for reason, which in turn means helping Monica to develop into a virtuous woman who wills the good for its own sake. But the height of Monica's virtue will consist in the love of God, and her love of God will both sooner and later unite her with what she loves. And so for God to love Monica is for God to do what he can to elicit Monica's love of him and in the end to unite Monica with himself. Understood in this way, Aquinas's account of God's love looks less like the repugnantly cerebral doctrine it initially seemed to be and more clearly in accord with our ordinary feeling of what divine love is and should be.

But this conclusion seems to heighten the perplexity with which this paper began. For the suffering of the damned in hell on the view of Dante and Aquinas (and most other traditional Christian thinkers) never ends and never eventuates in redemption. ${ }^{34} \mathrm{How}$, then, is their suffering reconcilable with the love of God? Answering this question requires a somewhat closer look at the Christian notions of heaven and hell. On Christian doctrine, heaven should be understood not as some place with gates of pearl and streets of gold but rather as a spiritual state of union with God; and union with God should be understood to involve as a necessary (but not a sufficient) condition the state of freely willing only what is in accord with the will of God. ${ }^{35}$ But if this is an appropriate description of the Christian doctrine of heaven, then it is not within God's power to ensure that all human beings will be in heaven, because it

34 ST. Ia, q. 64, a 2.

35 Cf. ST Ia Ilae, q. 3, a. 1, a. 2 ad 4 , and a. 4 ad 5. 
is not within the power even of an omnipotent entity to make a person freely will anything.

What, then, is God to do with those who will not be saved? In general (but with some notable exceptions), ${ }^{36}$ on Dante's view these are people who have willed to love some finite good, typically their own pleasure or power, in preference to the highest good which is God. They have been irrational in short, either because like the thieves in the Inferno they employ reason in a defective way, just to find the means to an end which is itself against reason, or because they fail to use reason to govern their passions, as is the case with Filippo Argenti. In either case, so far from actualizing their capacity for reason during their lives in such a way as to become habituated to a love of goodness, those in Dante's hell have become habituated to irrational acts. They have not acquired virtues during their lifetimes but vices, on Aquinas's understanding of the vices: stable dispositions to act contrary to their nature. ${ }^{37}$

This notion of vice is fruitful for understanding Dante's view of hell. On the one hand, the vices, the habitual actions of the damned, are irrational, destructive of the being of persons habituated to them, and hence bad or immoral; and so both the actions and the character of the damned are contrary to their nature. But, on the other hand, the vicious actions of the damned during their lifetime were habitual. By their own choices, as a result of recurrently willing to act in a way contrary to their nature, the damned while alive acquired stable dispositions to act in one or another irrational manner. Now a stable disposition, a lasting state of character, is itself a kind of nature; and we commonly refer to such a state as a second nature, an acquired cast of character which is produced over a period of time by our free choices and which is difficult to change.

So what God has on his hands in the case of those who eventually end up in Dante's hell is persons who will not will what they need to will in order for God to be able to unite them to himself in heaven ${ }^{38}$ and who by

36 The exceptions include, for example, the virtuous pagans and unbaptized babies.

37 ST Ia Ilae, q. 71, a. 1, and a. 2, and a. 3.

38 For Aquinas, what a person needs to will in order for God to save him is, in general, just the free act of will cooperating with God's grace, which does the work of sanctifying him. For a discussion of Aquinas's views on the role of grace and free will in God's redemptive work, see my 'Atonement According to Aquinas,' in Philosophy and the Christian Faith, ed. Thomas Morris (Notre Dame: Notre Dame University Press, forthcoming). 
their repeated irrational choices violating their nature have produced in themselves a second, vicious nature. It is not possible for God to bring such persons to heaven. ${ }^{39}$ Should he then annihilate them? To annihilate them is to eradicate their being; but to eradicate being on Aquinas's theory is a prima facie evil, which an essentially good God could not do unless there were an overriding good which justified it. Given Aquinas's identification of being and goodness, such an overriding good would have to produce or promote being in some way, but it is hard to see how the wholesale annihilation of persons could produce or promote being. In the absence of such an overriding good, however, the annihilation of the damned is not morally justified and thus not an option for a good God. On Aquinas's account, then, it is not open to God either to fulfill the natures of such persons or to eradicate them.

The genius of Dante's idea of hell is that it finds an intermediate between these two extremes. ${ }^{40}$ On Dante's view, what God does with the damned is treat them according to their second nature, the acquired nature they have chosen for themselves. He confines them within a place where they can do no more harm to the innocent. In this way he recognizes their evil nature and shows that he has a care for it, because by keeping the damned from doing further evil, he prevents their further disintegration, their further loss of goodness and of being. He cannot in-

39 This position will be disputed by those Thomists who believe Aquinas sees God only as determining and never determined. For some argument against the attitude of such Thomists, see my 'Atonement According to Aquinas.'

40 To explicate Dante's idea fully would go beyond the scope of this paper, because it would require a consideration of retributive punishment in hell and its compatibility with divine justice, as well as an evaluation of the doctrine that the damned in hell never repent of their evil and so never leave hell for heaven. As far as I understand it, Dante's idea seems to be that the retributive punishment the damned endure is a positive good for them, contributing to whatever spiritual health and well-being they have, and that something in the nature of the human state after death rules out the possibility of any spiritual alteration on the part of the damned. But to do justice to either part of this Dantean idea would require at least another paper; and furthermore, no matter how the evaluation of these doctrines turns out, Dante could, I think, abandon either doctrine and still preserve the essence of his idea of hell. So in the brief discussion of Dante which follows I will leave these other considerations to one side and focus just on the ways in which the Thomistic theory of morality and account of love support Dante's claim that his hell is founded on God's love. 
crease or fulfill the being of the damned; but by putting restraints on the evil they can do, he can maximize their being by keeping them from additional decay. In this way, then, he shows love - Aquinas's sort of love - for the damned.

And in the second place, in hell God provides for the damned a place in which they may still act and will in accordance with their nature, their second, self-chosen nature. It is not just a dramatic device to illustrate the nature of the sin that in his Inferno Dante makes the punishment fit the crime; it is a philosophical thought as well. Dante does not present hell as God's torture chamber in which the damned shriek insanely to eternity under the torments imposed by God. In fact, in the case of Filippo Argenti, it hardly seems true to say that his pains are imposed by God at all, for what Filippo suffers by way of physical pain is largely a result of what his companions in the Styx do to him and what he does to himself. Filippo's punishment is in a sense a natural consequence of the way he chooses to act. His wrathful behavior elicits the wrathful behavior of his wrathful companions; and his response to their beating him is to tear himself with his teeth in wrath. Because of the nature he has given himself, the closest Filippo Argenti can come to the natural functioning of a human being is to act in wrath. By granting him a place in which to exercise his wrathfulness, God allows him as much being, and thus as much goodness, as Filippo is capable of. God does what he can, then, to preserve and maximize Filippo's being and the being of each of the damned. In so doing he treats the damned according to their nature and promotes their good; and because he is goodness itself, by maximizing the good of the damned, he comes as close as he can to uniting them with himself - that is to say, he loves them.

In this short paper I have rushed through one major piece of Thomistic metaphysics or philosophical theology after another; their cogency and philosophical respectability are not to be judged on the basis of the scanty treatment I have given them here. In the same way I have emphasized Dante's treatment of the wrathful, leaving aside the various cases (such as that of the damned in Limbo) which would require exceptions or refinements to the general idea I have been at pains to present here. What all this rushing and simplifying has been in aid of is the presentation of the outlines of an idea of Aquinas and Dante which I take to be philosophically interesting, theologically consistent, and artistical- 
ly brilliant - that in all the sufferings of his creatures, even in the unending pains of hell, God's love is at work. ${ }^{41}$

Received October 1985

41 I am grateful to Diogenes Allen, Mohan Matthen, Scott MacDonald, and Peter van Inwagen for thoughtful comments and questions on an earlier draft of this paper. I'm especially grateful to Norman Kretzmann for numerous helpful suggestions, and I'm indebted to John Crossett, whose efforts on my behalf made this paper possible. 